\title{
Demonstration of Defective C3-Receptor-mediated Clearance by the Reticuloendothelial System in Patients with Acquired Immunodeficiency Syndrome
}

\author{
Bradley S. Bender, ${ }^{\star \ddagger}$ John F. Bohnsack, Stephanie H. Sourlis, ${ }^{\text {t5 }}$ Michael M. Frank, ${ }^{5}$ and Thomas C. Quinn ${ }^{\neq 5}$ \\ ${ }^{*}$ Clinical Immunology Section, National Institute on Aging, Baltimore, Maryland $21224 ;{ }^{\ddagger}$ Division of Infectious Diseases, \\ The Johns Hopkins Hospital, Baltimore, Maryland 21205; and ${ }^{\S}$ Laboratory of Clinical Investigation, National Institute of Allergy and \\ Infectious Diseases, Bethesda, Maryland 20205
}

\begin{abstract}
The function of macrophage $\mathrm{C} 3$ receptors was assessed in vivo by measuring the clearance of $\mathrm{C} 3$-sensitized autologous erythrocytes in seven acquired immunodeficiency syndrome (AIDS) patients, eight healthy homosexual men, eight healthy heterosexual men, and four infected controls. Healthy heterosexual men had an initial clearance of $50.1 \pm 2.0 \%$ of the inoculum, with a release of a small portion of these cells $(10.9 \pm 1.3 \%)$ into the circulation. Healthy homosexual men had a greater initial clearance of $66.0 \pm 4.2 \%(P<0.01)$ followed by a similar release $(14.0 \pm 3.3 \%)$. AIDS patients had an initial clearance of $60.6 \pm 7.5 \%$ but had a relatively large release of cells $(25.6 \pm 3.2 \%)$ ( $P<0.005$ vs. heterosexuals; $P<0.05$ vs. homosexuals), suggesting a failure of macrophage phagocytosis. Infected controls had an initial clearance of $59.4 \pm 4.9 \%$, with a release of $19.6 \pm 3.8 \%$ ( $P=$ NS vs. AIDS). These data, in addition to Fcreceptor dysfunction, demonstrate a global reticuloendothelial system dysfunction in AIDS patients. This may contribute to their frequent infections with opportunistic pathogens and inappropriate immune responses against these microorganisms.
\end{abstract}

\section{Introduction}

Among the most striking features of acquired immunodeficiency syndrome (AIDS) are the broad array of disseminated opportunistic pathogens and the occurrence of aggressive forms of previously rare neoplasms. These diseases occur because of profound defects in cell-mediated immunity (1). Most authorities agree that a newly described retrovirus, now referred to as human immunodeficiency virus (HIV) ${ }^{1}(2)$, is the causative agent of AIDS. It appears that the virus enters the helper/inducer subset of lymphocytes of infected persons via attachment to the T4 surface antigen $(3,4)$, eventually leading to cytolysis and ultimate suppression of cell-mediated immunity $(5,6)$.

Data suggest that HIV can additionally infect monocytes and macrophages, as shown by reports of HIV-like particles in

This work was presented in part at the First International Congress on Acquired Immunodeficiency Syndrome, 16 April 1985, Atlanta, GA.

Address correspondence and reprint requests to Bradley S. Bender, M.D., Geriatric Research, Education and Clinical Center, Veterans Administration Medical Center, Gainesville, FL 32602.

Received for publication 10 December 1985 and in revised form 29 October 1986.

1. Abbreviations used in this paper: HIV, human immunodeficiency virus; RES, reticuloendothelial system.

The Journal of Clinical Investigation, Inc.

Volume 79, March 1987, 715-720 macrophages of patients with $\operatorname{AIDS}(7,8)$. This conclusion is also supported by the fact that HIV bears strong resemblance to visna virus (9), a pathogenic lentivirus known to infect monocytes (10). Recently, it has been shown that cells of the monocyte-macrophage series can be infected in vitro with HIV (11, 12). Moreover, macrophages cultured from the brain or lung of patients with AIDS were found to harbor HIV (12). In addition, it has been well documented that there is monocyte-macrophage dysfunction in AIDS (13-21). Studies in patients with AIDS have demonstrated decreased numbers of monocytes and macrophages (13-16), the presence of atypical peripheral blood monocytes (16), impaired chemotaxis $(15,17)$, defective phagocytosis (17), abnormal secretion of interleukin-1 (18), and impaired monocyte help for the in vitro proliferative response of lymphocytes (19). We have also demonstrated in vivo that Fcreceptor-specific function of the reticuloendothelial system (RES) in patients with AIDS is abnormal, as shown by defective clearance from the circulation of IgG-sensitized autologous erythrocytes (20). This in vivo defect appears to correlate with an in vitro defect in monocyte antibody-dependent cell-mediated cytotoxicity (21).

Other immunologically active membrane receptors on mononuclear phagocytes are the receptors for fragments of the complement component $\mathrm{C} 3$. Along with cofactors, this receptor promotes attachment and ingestion by cells of the RES of C3band $\mathrm{iC} 3 \mathrm{~b}$-coated particles. To define and characterize more fully the level of in vivo mononuclear cell phagocyte function in patients with AIDS, we studied the clearance from the circulation of C3-coated, ${ }^{51} \mathrm{Cr}$-labeled and anti-Rh $\mathrm{h}_{0}(\mathrm{D})$-coated, ${ }^{51} \mathrm{Cr}$-labeled autologous erythrocytes. These studies demonstrate marked immune clearance defects in patients with AIDS. Furthermore, the kinetics strongly suggest that there is an in vivo macrophage phagocytic defect in patients with AIDS.

\section{Methods}

Subjects. We studied seven patients with AIDS, who fulfilled the Centers for Disease Control definition. One patient presented with Kaposi's sarcoma and Pneumocystis carinii pneumonia; six presented with other opportunistic infections with no history of an underlying immunosuppressive disorder or therapy (22). Six of the patients were homosexual or bisexual men (one of whom also had received a blood transfusion) and one was a female intravenous drug abuser. Their clinical and laboratory features are presented in Table I. No patient had any evidence of hepatic disease at the time of the study and six were hospitalized for treatment of their infections. Three control groups were chosen. Two groups consisted of eight healthy heterosexual men and eight healthy homosexual men, none of whom had swollen lymph nodes on examination or recent histories of weight loss, fevers, or diarrhea. The third control group consisted of four patients with prolonged infections but not AIDS. These were lepromatous leprosy, infectious mononucleosis, 


\begin{tabular}{|c|c|c|c|c|c|}
\hline Age & Sex & Risk group & Diagnoses & $\begin{array}{l}\text { T-helper/ } \\
\text { T-suppressor } \\
\text { ratio }\end{array}$ & $\begin{array}{l}\text { Antibody } \\
\text { to HIV }\end{array}$ \\
\hline 34 & $\mathbf{M}$ & Homosexual & Kaposi's sarcoma & 0.02 & + \\
\hline 42 & $\mathbf{M}$ & Homosexual & Pneumocystis carinii pneumonia & 0.02 & + \\
\hline 34 & $\mathbf{M}$ & Homosexual & Cytomegalovirus (disseminated) & 0.24 & + \\
\hline 29 & $\mathrm{~F}$ & IV drug abuser & Central nervous system Toxoplasma gondii & 0.40 & + \\
\hline 40 & $\mathbf{M}$ & $\begin{array}{l}\text { Blood product recipient, } \\
\text { bisexual }\end{array}$ & Pneumocystis carinii pneumonia & 0.30 & + \\
\hline 28 & $\mathbf{M}$ & Homosexual & Cryptosporidium species diarrhea & 0.19 & + \\
\hline 36 & $\mathbf{M}$ & Homosexual & Central nervous system Toxoplasma gondii & 0.11 & + \\
\hline
\end{tabular}

recurrent pneumonia, and Hemophilus parainfluenzae endocarditis. No patient had any underlying illnesses or was taking a drug known to affect immune function. All patients and volunteers gave informed, written consent.

Clearance studies. The clearance studies were modified from Jaffe et al. (23). Blood was obtained by venipuncture into a heparinized syringe. The erythrocytes were isolated by centrifugation at $500 \mathrm{~g}$ at $4^{\circ} \mathrm{C}$, washed three times with cold physiologic saline, photometrically standardized to $6.6 \times 10^{8} \mathrm{cells} / \mathrm{ml}$ and radiolabeled with ${ }^{51} \mathrm{Cr}$ by incubating at $37^{\circ} \mathrm{C}$ for 30 min with $10 \mu \mathrm{Ci}$ of $\mathrm{Na}_{2}{ }^{51} \mathrm{CrO}_{4}$ (ICN Biomedicals, Inc., Irvine, CA) per milliliter of cell suspension. The radiolabeled erythrocytes were then washed twice in cold saline and photometrically standardized to $3.3 \times 10^{8} \mathrm{cells} / \mathrm{ml}$. IgM cold agglutinin was obtained from the plasma of a patient with chronic idiopathic cold agglutinin disease as previously described (24). An aliquot of these cells was mixed with IgM cold agglutinin and incubated in an ice water bath for $45 \mathrm{~min}$. Without washing, an equal volume of fresh autologous serum (as a source of complement) was added to the mixture and incubated at $18^{\circ} \mathrm{C}$ for $30 \mathrm{~min}$, followed by $5 \mathrm{~min}$ at $37^{\circ} \mathrm{C}$ to allow the cold agglutinin to disassociate. After incubation, the cells were washed twice in physiologic saline, resuspended at $3.3 \times 10^{8}$ cells $/ \mathrm{ml}$ in normal saline, diluted 10 -fold with saline and injected via a butterfly needle through a forearm vein. Nine samples of venous blood were taken over a 2-h interval and clearance curves were drawn.

For Fc-specific clearance studies, an aliquot of the ${ }^{51} \mathrm{Cr}$-labeled erythrocytes (at $3.3 \times 10^{8}$ cells $/ \mathrm{ml}$ ) was sensitized by the dropwise addition of purified, aggregate-free IgG-anti- $R h_{0}(D)$. This mixture was incubated at $37^{\circ} \mathrm{C}$ for $30 \mathrm{~min}$, washed twice in physiologic saline, resuspended as above, and injected via a forearm vein. Erythrocyte survival was determined by timed serial bleedings and was calculated by determining the clearance half-time of the erythrocytes (the time in which $50 \%$ of the labeled cells were removed from circulation).

Complement assays. Levels of Factor $\mathrm{H}$ and Factor I were measured by radioimmunoassay (25) and expressed as percent of control value. $\mathrm{C} 4$ and total serum complement hemolytic activity $(\mathrm{CH} 50)$ were assayed by hemolytic titration (25). C3 was quantitated with commercially available immunodiffusion plates (Behring Diagnostics, Somerville, NJ).

Other studies. Peripheral blood lymphocytes were labeled with the monoclonal antibodies OKT4 (T-helper cell) and OKT8 (T-suppressor cell) and OKT3 (pan T cells), (Ortho Diagnostic Systems, Inc., Raritan, NJ) and analyzed by flow cytometry. Antibodies to HIV were detected by an enzyme-linked immunoabsorbent assay (Litton Bionetics, Inc., Kensington, MD) and their specificity was confirmed by Western blot technique.

Statistical analysis. Comparison of means was done by the Wilcoxon rank sum test.

\section{Results}

Patient characteristics. The clinical and laboratory features of the seven patients with AIDS are listed in Table I. Sera from all seven AIDS patients were positive for antibody to HIV. Their mean $\mathrm{T}$-helper/T-suppressor ratio was $0.18 \pm 0.05$. The eight healthy homosexual men who served as controls had a mean of $\mathrm{OKT}^{+} / \mathrm{OKT}^{+}$ratio $=1.2 \pm 0.25$ and included three with $\mathrm{T}$ helper/T-suppressor ratios $<1.0$. Two control homosexual men were seropositive for HIV and had $\mathrm{OKT} 4^{+} / \mathrm{OKT} 8^{+}$ratios of 1.2 and 0.8. All eight healthy heterosexual men had T-helper/Tsuppressor ratios $>1.0$ and none were seropositive for HIV. All four infected control patients were seronegative for HIV, and all had an $\mathrm{OKT} 4^{+} / \mathrm{OKT} 8^{+}$ratio $>1.0$ except for the patient with infectious mononucleosis, who had a 0.8 ratio.

C3-mediated clearance. Infusion of $\mathrm{C} 3$-sensitized erythrocytes is followed by a triphasic clearance curve $(23,24)$. There is an initial rapid clearance of cells from the circulation due to attachment to $\mathrm{C} 3$ receptors of RES cells, primarily hepatic macrophages (Kupffer cells). The attached red cells then undergo one of two fates. A portion of the cells are phagocytosed, and the remainder are released back into the circulation due to the cleavage of the membrane-bound complement components. Following release from their sites of sequestration, these cells circulate with a half-time equal to unsensitized cells.

Fig. 1 depicts the clearance curves for the patients with AIDS and the healthy heterosexual and homosexual controls. At the degree of sensitization chosen, a large portion of the sensitized cells was cleared in healthy heterosexual men during the initial $10 \mathrm{~min}$. The nadir of the clearance occurred between 10 and 20 min with $50.1 \pm 2.0 \%$ of the initial inoculum cleared. Due to the cleavage of the $\mathrm{C} 3$ fragments, a portion of the cells were released

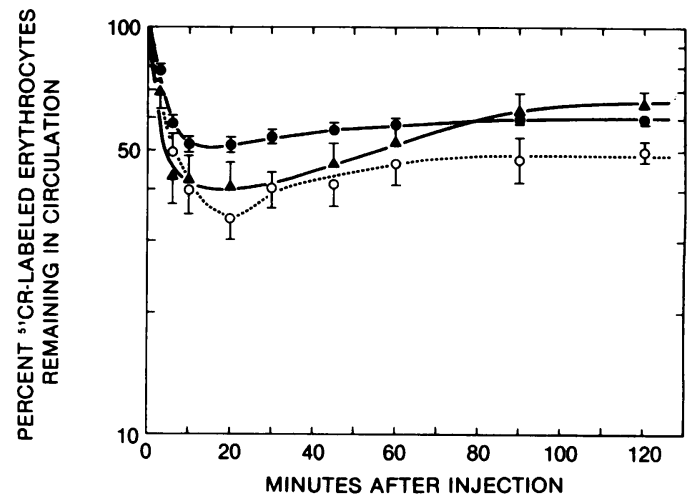

Figure 1. Clearance of C3-sensitized, ${ }^{51} \mathrm{Cr}$-labeled autologous erythrocytes from the circulation for healthy heterosexual men (solid circles), healthy homosexual men (open circles), and patients with AIDS (triangles). Values are mean \pm SEM at each point. 
back into the circulation so that in heterosexual men a plateau value of $60.8 \pm 1.9 \%$ of the inoculum was seen. This represents a mean release of $10.9 \pm 1.3 \%$ of the inoculum back into the circulation.

Healthy homosexual men had a greater initial clearance of $66.0 \pm 4.2 \%$ ( $P<0.01$ vs. heterosexual men) of the inoculum followed by a lower level of return to a plateau value of $48.0 \pm 6.5 \%$ ( $P<0.05$ vs. heterosexual men). As with heterosexual men, only a relatively small portion of the cells $(14.0 \pm 3.3 \%, P$ $=0.8$ ) was released back into the circulation. No differences were seen between the two HIV seropositive and the six seronegative healthy homosexual men.

Patients with AIDS had clearance curves that were both qualitatively and quantitatively different from these two control groups. In patients with AIDS there was a relatively large initial clearance of $60.6 \pm 7.5 \%$ of the initial inoculum. However, patients with AIDS had a relatively large release back into the circulation of $25.6 \pm 3.2 \%$ ( $P<0.005$ vs. heterosexual controls; $P<0.05$ vs. homosexual controls), so that a high plateau value of $65.0 \pm 6.3 \%$ was seen.

We considered the possibility that the observed clearance kinetics in AIDS patients was secondary to infection with opportunistic pathogens. We therefore studied four patients with infections but not AIDS. The results are shown in Fig. 2. The infected control group had an initial clearance of $59.4 \pm 4.9 \%$ of the inoculum with a release of $19.6 \pm 3.8 \%$ to a plateau value of $60.2 \pm 3.5 \%$. These values are essentially identical to those seen in patients with AIDS.

To determine if this clearance defect in AIDS patients could be overcome with increased amounts of cold agglutinin antibody (and thus increased C3), one patient was studied after sensitization of his erythrocytes with twice the standard dose of IgM cold agglutinin. The results are shown in Fig. 3 and demonstrate that despite a larger initial clearance, a large portion of cells were still released back into the circulation.

IgG Fc-receptor mediated clearance. Infusion of IgG-sensitized erythrocytes is followed by progressive splenic sequestration and destruction. For the time period studied, the clearance follows first order kinetics so that a half-time can be determined. No differences in clearance half-times were observed between healthy heterosexual or healthy homosexual men (20). The clearance curves of five patients with AIDS are displayed in Fig. 4. Four of the patients had prolonged clearances clearly outside

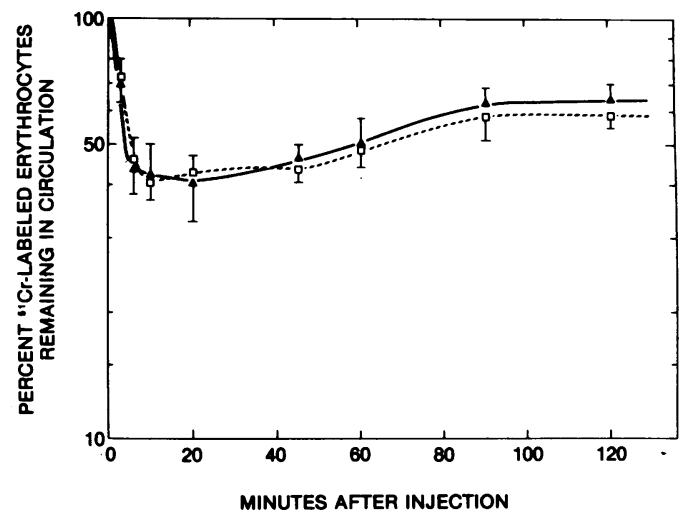

Figure 2. Clearance of $\mathrm{C} 3$-sensitized, ${ }^{51} \mathrm{Cr}$-labeled autologous erythrocytes from the circulation for patients with AIDS (triangles) and patients with infections but not AIDS (squares).

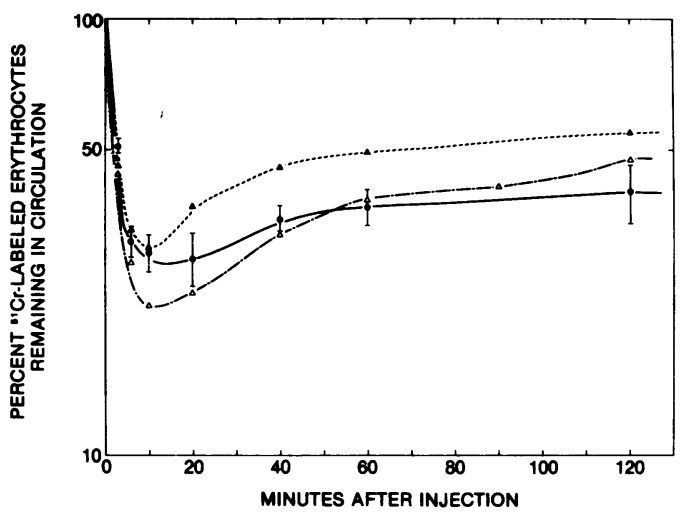

Figure 3. Clearance of C3-sensitized, ${ }^{51} \mathrm{Cr}$-labeled autologous erythrocytes that have been sensitized with twice the "standard" number of C 3 components. Closed circles and vertical bars are mean \pm SEM for three healthy heterosexual men. Solid triangle is the clearance of an AIDS patient with the "standard" number of $\mathrm{C} 3$ components; open triangle is clearance with twice the "standard" number.

the normal range, whereas one patient had a slightly accelerated clearance. Interestingly, this patient with relatively rapid clearance had the smallest release in C3-mediated clearance (18\%) compared with releases of $26-33 \%$ for the four patients with prolonged Fc-receptor-specific clearances.

Complement assays. Upon activation, $\mathrm{C} 3$ is cleaved into two fragments, $\mathrm{C} 3 \mathrm{a}$ and $\mathrm{C} 3 \mathrm{~b}$. C3b may bind to the erythrocyte surface and mediate clearance. The level of cell-bound $\mathrm{C} 3 \mathrm{~b}$ is controlled by two serum proteins, Factor $\mathrm{H}(\beta 1 \mathrm{H})$ and Factor I (C3b inactivator), as well as an intrinsic cell membrane protein (CR1). Factors $\mathrm{H}$ and $\mathrm{I}$ acting on $\mathrm{C} 3 \mathrm{~b}$ can convert it to $\mathrm{C} 3 \mathrm{bi}$. In the presence of $\mathrm{CR} 1$, Factor I can cleave $\mathrm{C} 3 \mathrm{~b}$ further to a smaller C3 cleavage fragment, C3dg. C3dg does not mediate erythrocyte clearance.

Because increased serum levels of Factors $\mathrm{H}$ and I could modify C3 clearance kinetics, especially the release back into the circulation, we assayed the subjects' sera for these factors. The results are shown in Table II. No significant differences were found between healthy controls, patients with AIDS, or patients with other infections. Moreover, no differences were found in serum levels of $\mathrm{C} 3, \mathrm{C} 4$, or $\mathrm{CH} 50$ between healthy controls and patients with AIDS (data not shown).

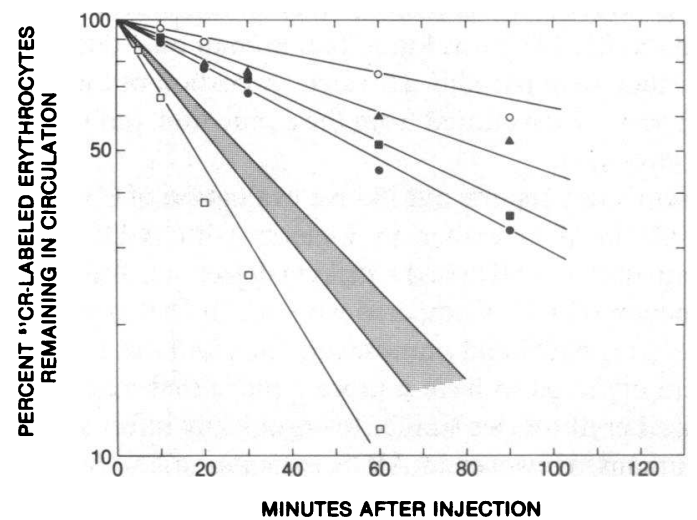

Figure 4. Survival of IgG-sensitized ${ }^{51} \mathrm{Cr}$-labeled autologous erythrocytes. The shaded area is the mean \pm SEM for 12 volunteers, and the individual clearance curves are five patients with AIDS. 
Table II. Serum Factor $H$ and Factor I Levels

\begin{tabular}{llll}
\hline & $\mathrm{N}$ & Factor $\mathrm{H}^{*}$ & Factor $\mathrm{I}^{\sharp}$ \\
\hline & & $\%$ & $\%$ \\
$\begin{array}{l}\text { Homosexual men without HIV } \\
\quad \text { infection }\end{array}$ & 4 & $102 \pm 19^{\ddagger}$ & $100 \pm 16$ \\
$\begin{array}{l}\text { Patients with AIDS } \\
\text { Patients with infections but not AIDS }\end{array}$ & 4 & $119 \pm 22$ & $102 \pm 28$ \\
& & $100 \pm 4$ & $100 \pm 8$ \\
\hline
\end{tabular}

* Percent C3c released with 1:5,000 dilution of serum, expressed as percent of control value obtained with heterosexual men.

${ }^{\ddagger}$ Mean \pm SD.

${ }^{5}$ Dilution causing $50 \%$ release of ${ }^{125} \mathrm{I}-\mathrm{C} 3 \mathrm{c}$, expressed as percent of control value obtained with heterosexual men.

\section{Discussion}

Shortly after the initial observation that intravenous injection of particulate dyes were cleared by phagocytic cells of the RES, the concept was developed that there exists a system of fixed phagocytic cells, residing principally in blood vessels and sinusoids of the liver and spleen, that is responsible for removing invading organisms from the circulation (26). It is well recognized that specific membrane receptors on mononuclear phagocytes are functionally important in the attachment and ingestion of many kinds of particulate materials. It is now possible to evaluate the functional status of these receptors by determining the clearance kinetics of autologous radiolabeled erythrocytes sensitized with either IgG-anti-RH $\mathrm{H}_{0}(\mathrm{D})$ antibody or the complement component C3 (27). In terms of functional activity as reflected in sites of sequestration, receptors for the Fc portion of $\mathrm{IgG}$ can be considered largely present on splenic macrophages, whereas C3 receptors are maximally efficient in their site on hepatic Kupffer cells (27).

Studies of in vivo C3 clearance initially focused on experimental animals $(28,29)$. It was shown that guinea pigs rapidly clear C3-coated erythrocytes from the circulation via attachment to Kupffer cell C3 receptors. Such attachment did not lead to phagocytosis unless the phagocytic cells were stimulated by a second signal such as IgG antibody or were activated by infections of the animal. Activated macrophages were more effective in clearing C3-coated erythrocytes and phagocytosed the C3-coated red cells in the absence of a second signal. In the normal animal virtually all the cleared cells were returned to the circulation as the membrane-bound C3 was cleaved. When these studies were repeated in man $(23,24)$ it was found that human macrophages behaved as if they were partially activated. A portion of the C3coated erythrocytes were cleared from the circulation, but many were phagocytosed.

This present study reports our in vivo evaluation of C3- and Fc-receptor-mediated clearance in patients with AIDS. We found that patients with AIDS had a striking defect in C3-specific clearance function (Fig. 1). Compared with healthy heterosexual men, patients with AIDS and homosexual men without known infection were observed to have a more rapid initial clearance of C3-sensitized erythrocytes similar to chronically infected animals and humans. However in AIDS patients, unlike homosexuals without known infections, there was a release of a relatively large number of labeled erythrocytes back into the circulation and efficient phagocytosis did not occur. Interestingly, this was noted in a number of other infected individuals as well (Fig. 2).
There are several possible mechanisms that might explain this failure to phagocytose the cleared cells. First, there may be increased amounts of serum factor $\mathrm{H}(\beta 1 \mathrm{H})$ or factor I $(\mathrm{C} 3 \mathrm{~b}$ inactivator) in patients with AIDS so that the $\mathrm{C} 3$ components on the sensitized erythrocytes are cleaved before erythrophagocytosis occurs. However, we found no difference in the serum levels of these factors between patients with AIDS and either healthy homosexual or heterosexual men. Second, there could be different numbers of $\mathrm{C} 3$-receptors on the hepatic macrophages of patients with AIDS. Investigators have reported that the number of $\mathrm{C} 3 \mathrm{~b}$ receptors on the erythrocytes of patients with AIDS is decreased as compared with controls (30). However, if the number of $\mathrm{C} 3 \mathrm{~b}$ receptors on mononuclear phagocytes was also decreased, one might expect to see a smaller initial clearance rather than a larger initial clearance as seen in our patients. Furthermore, when we increased the number of binding sites on the injected erythrocytes, we found that the initial clearance increased but there was still a relatively large release of cells (Fig. 3). Third, there may be a defect in the level of macrophage activation and/or phagocytosis. In a preliminary communication, we reported studies on RES Fc-receptor-specific clearance in patients with AIDS (a study of splenic macrophage function) (20). In this previous study, 11 of 15 AIDS patients $(P<0.0005)$ had a clearance half-time longer than that of the upper $95 \%$ confidence interval of the healthy controls. Interestingly, in this assay, patients with infections but without AIDS, had significantly different clearances than patients with AIDS. No correlation was seen with immune complexes, complement levels, HLA phenotypes, or numbers of peripheral blood lymphocyte subsets. There was a clear correlation, however, with subsequent disease course. 8 of 11 patients with AIDS and defective clearances subsequently died as compared with one of four patients with AIDS and normal clearance rate (20). These in vivo RES defects led us to study the function of peripheral blood monocytes in an in vitro antibody-dependent cell-mediated cytotoxicity assay with chicken erythrocytes as target cells. Patients with AIDS were found to have defective phagocytic ability in this assay compared with healthy controls (21). Furthermore, sera from AIDS patients suppressed antibody-dependent cell-mediated cytotoxicity of peripheral blood mononuclear cells of healthy subjects (21). Additionally, defective mononuclear cell phagocytosis of some infectious pathogens has been reported in patients with $\operatorname{AIDS}(17,31)$. These prior in vitro studies and our current in vivo data clearly indicate the presence of defective mononuclear cell phagocytosis in patients with AIDS. These findings help explain the frequent occurrence of opportunistic infections and the inappropriate immune response of the AIDS patient to these pathogens.

The next issue that needed to be addressed was whether the observed clearance abnormality and probable phagocyte defect was due to HIV infection or was a secondary phenomenon. The issue is not completely resolved, but the following points can be made. First, the abnormality is unlikely to be due to infection with HIV itself because the clearance curves of our healthy homosexual men bore no relation to whether they were HIV seropositive or seronegative. Our data do suggest, however, that it may be secondary to infection with other organisms as the clearance curves of our infected control patients were very similar to those of patients with AIDS (Fig. 2). These patients were selected because they all had a prolonged ongoing infection but no other recognizable defect in immune function. One possible explanation is that with prolonged infection, the macrophages may become "overloaded" and lose some phagocytic ability. A 
second possibility is that these patients' infections were prolonged because of an underlying defect in C3-clearance function, though we have no other evidence to support this contention. A third possibility is that in patients with infections, the macrophages themselves have surface-bound proteolytic enzymes that cleave erythrocyte-bound $\mathrm{C} 3$, thus releasing an increased number of cells into the circulation. Supporting this hypothesis is our observation that normal human neutrophils have the capacity to cleave sheep red cell-bound C3b (32). Finally, the similarity in clearance function between the two groups also suggests that the abnormality in clearance function is not due to a reduction in the number or function of OKT4 ${ }^{+}$lymphocytes, because all the control patients with infections except for the patient with infectious mononucleosis had a normal $\mathrm{OKT} 4^{+} / \mathrm{OKT}^{+}$ratio.

Of additional interest is the observed clearance kinetics of the healthy homosexual men (Fig. 1). The curve is similar to that seen in guinea pigs experimentally infected with bacillus Calmette-Guerin (29), thus suggesting that healthy, asymptomatic homosexual men have an activated RES. This is not surprising, since the lifestyle of many homosexual men leads to multiple exposures to infectious agents with consequent prolonged antigenic stimulation. Other reported immune abnormalities in healthy homosexual men include reversal of the $\mathrm{OKT}^{+} / \mathrm{OKT}^{+}$ratio due to an increase in $\mathrm{OKT}^{+}$cells $(33-$ 35 ), decreased proliferative response to mitogens (35), cutaneous anergy (17), elevated immunoglobulins $(36,37)$, and presence of circulating immune complexes (37).

A variety of defects in the monocyte-macrophage cell have been reported in patients with AIDS. First, they have decreased numbers of pulmonary macrophages obtained by bronchoalveolar lavage $(13,14)$. Microscopic examination of peripheral white blood cells has revealed decreased percent representation and absolute numbers of peripheral blood monocytes $(15,16)$, the presence of large atypical peripheral blood monocytes with a fine nuclear chromatin, and one or more cytoplasmic vacuoles (16). Decreased chemotaxis with defective migratory function has been described $(15,17)$. The monocytes have decreased ability to secrete interleukin- 1 in response to appropriate stimulants (18), although they can respond to gamma interferon (38). Impaired monocyte phagocytosis and killing of some but not all pathogens has been reported $(17,18,31)$. Finally, there is defective monocyte help in in vitro proliferative response of lymphocytes (19).

When considered together these studies document the presence of monocyte dysfunction in AIDS. Whether these are due to actual infection of the monocytes by $\operatorname{HIV}(11,12)$ or are secondary to its effects on other cells $(1,3,6)$ needs clarification. Additional studies on mononuclear phagocyte function in relation to HIV infection are clearly indicated to define further the immunopathology of AIDS.

\section{Acknowledgments}

We are grateful to Dr. Eric Brown for assistance in preparing and standarding the IgM cold agglutinin, Ms. Thelma Gaither for performing the complement assays, and Ms. Eleanor Wielechowski for secretarial assistance.

\section{References}

1. Fauci, A. S., A. M. Macher, D. L. Longo, H. C. Lane, A. H. Rook, H. Masur, and E. P. Gelmann. 1984. Acquired immunodeficiency syndrome: epidemiologic, clinical, immunologic, and therapeutic considerations. Ann. Intern. Med. 100:96-106.
2. Coffin, J., A. Haase, J. A. Levy, L. Montagnier, S. Oroszlan, N. Teich, H. Temin, K. Toyoshima, H. Varmus, P. Vogt, and R. Weiss. 1986. What to call the AIDS virus. Nature (Lond.). 321:10.

3. Klatzmann, D., F. Barre-Sinoussi, M. T. Nugeyre, C. Dauguet, E. Vilmer, C. Griscelli, F. Brun-Vezinet, C. Rouzious, J. C. Gluckmann, J. C. Chermann, and L. Montagnier. 1984. Selective tropism of lymphadenopathy associated virus (LAV) for helper-inducer T lymphocytes. Science (Wash. DC). 225:59-63.

4. Dalgeish, A. G., P. C. L. Beverly, P. R. Clapham, D. H. Crawford, M. F. Greaves, and R. A. Weiss. 1984. The CD4(T4) antigen is an essential component of the receptor for the AIDS retrovirus. Nature (Lond.). 312: 763-767.

5. Broder, S., and R. C. Gallo. 1984. A pathogenic retrovirus (HTLVIII) linked to AIDS. N. Engl. J. Med. 311:1292-1297.

6. Seligmann, M., L. Chess, J. L. Fahey, A. S. Fauci, P. J. Lachmann, J. L'Age-Stehr, J. Ngu, A. J. Pinching, F. S. Rosen, T. J. Spira, and J. Wybran. 1984. AIDS: an immunologic reevaluation. N. Engl. J. Med. 311:1286-1292.

7. Gvorkey, F., J. L. Melnick, J. G. Sinkovics, and P. Gyorkey. 1985. Retrovirus resembling HTLV in macrophages of patients with AIDS. Lancet. 1:106.

8. Kostianovsky, M., Y. H. Kang, and P. M. Grimley. 1983. Disseminated tubuloreticular inclusions in acquired immunodeficiency syndrome (AIDS). Ultrastruct. Pathol. 4:331-336.

9. Gonda, M. A., F. Wong-Staal, R. C. Gallo, J. E. Clements, O. Narayan, and R. V. Gilden. 1985. Sequence homology and morphologic similarity of HTLV-III and visna virus, a pathogenic lentivirus. Science (Wash. DC). 227:173-177.

10. Narayan, O., J. S. Wolinsky, J. E. Clements, J. D. Strandberg, D. E. Griffin, and L. E. Cork. 1982. Slow virus replication: the role of macrophages in the persistence and expression of visna virus of sheep and goats. J. Gen. Virol. 59:345-351.

11. Levy, J. A., J. Shimabukuro, T. McHugh, C. Casavant, D. Stites, and L. Oshiro. 1985. AIDS-associated retroviruses (ARV) can productively infect other cells besides human T helper cells. Virology. 147:441448.

12. Gartner, S., P. Markovits, D. M. Markovitz, M. H. Kaplan, R. C. Gallo, and M. Popovic. 1986. The role of mononuclear phagocytes in HTLV-III/LAV infection. Science (Wash. DC). 233:215-219.

13. Venet, A., G. Dennewold, D. Sandron, M. Stern, F. Jaubert, and J. Leibowitch. 1983. Bronchoalveolar lavage in the acquired immunodeficiency syndrome. Lancet. 2:53.

14. Rankin, J. A., P. D. Waltzer, J. M. Dwyer, C. E. Schrader, R. E. Enriques, and W. W. Merrill. 1983. Immunologic alterations in bronchoalveolar lavage in the acquired immunodeficiency syndrome. Am. Rev. Respir. Dis. 128:189-194.

15. Smith, P. D., K. Ohura, H. Masur, H. C. Lane, A. S. Fauci, and S. M. Wahl. 1984. Monocyte function in the acquired immune deficiency syndrome. J. Clin. Invest. 74:2121-2128.

16. Spivak, J. L., B. S. Bender, and T. C. Quinn. 1984. Hematologic abnormalities in the acquired immune deficiency syndrome. Am. J. Med. 77:224-228.

17. Pinching, A. J., D. J. Jeffries, M. Donaghy, P. E. Munday, T. J. McManus, O. Moshtael, J. M. Parkin, and J. R. W. Harris. 1983. Studies of cellular immunity in male homosexuals in London. Lancet. 2:126130.

18. Fauci, S. F. 1984. Immunologic abnormalities in the acquired immunodeficiency syndrome (AIDS). Clin. Res. 32:491-499.

19. Prince, H. E., D. J. Moody, B. I. Shubin, and J. L. Fahey. 1985. Defective monocyte function in acquired immune deficiency syndrome (AIDS): evidence from a monocyte-dependent T-cell proliferative system. J. Clin. Immunol. 5:21-25.

20. Bender, B. S., M. M. Frank, T. J. Lawley, W. J. Smith, C. M. Brickman, and T. C. Quinn. 1985. Defective reticuloendothelial system Fc-receptor function in patients with the acquired immunodeficiency syndrome. J. Infect. Dis. 152:409-412.

21. Bender, B. S., F. A. Auger, T. C. Quinn, R. Redfield, J. Gold, and T. M. Folks. 1985. Impaired antibody-dependent cell-mediated cy- 
totoxic activity in patients with the acquired immunodeficiency syndrome. Clin. Exp. Immunol. 64:166-172.

22. Centers for Disease Control. 1985. Revision of the case definition of acquired immunodeficiency syndrome for national reporting: United States. MMWR. 34:373-375.

23. Jaffe, C. J., J. M. Vierling, E. A. Jones, T. J. Lawley, and M. M. Frank. 1978. Receptor specific clearance by the reticuloendothelial system in chronic liver diseases. J. Clin. Invest. 62:1068-1077.

24. Atkinson, J. P., and M. M. Frank. 1974. Studies on the in vivo effects of antibody. Interaction of IgM antibody and complement in the immune clearance and destruction of erythrocytes in man. J. Clin. Invest. 54:334-348.

25. Gaither, T. A., C. H. Hammer, and M. M. Frank. 1979. Studies of the molecular mechanisms of $\mathrm{C} 3 \mathrm{~b}$ inactivation and a simplified assay of $\beta 1 \mathrm{H}$ and the C3b inactivator (C3b INA). J. Immunol. 123:11951204.

26. Aschoff, L. 1924. Das reticulolendotheliale system. Erger. Inn. Med. Kinderheilkd. 26:1-118.

27. Frank, M. M., T. J. Lawley, M. I. Hamburger, and E. J. Brown. 1983. Immunoglobulin G Fc receptor-mediated clearance in autoimmune diseases. Ann. Intern. Med. 98:206-218.

28. Schreiber, A. D., and M. M. Frank. 1972. Role of antibody and complement in the immune clearance and destruction of erythrocytes. I. In vivo effects of IgG and IgM complement fixing sites. J. Clin. Invest. 51:575-582.

29. Atkinson, J. P., and M. M. Frank. 1974. The effect of bacillus Calmette-Guerin-induced macrophage activation on the in vivo clearance of sensitized erythrocytes. J. Clin. Invest. 53:1742-1749.

30. Tausk, F. A., J. A. McCutchan, P. Spechko, R. O. Schreiber, and I. Gigli. 1986. Altered erythrocyte C3b receptor expression, immune complexes, and complement activation in homosexual men in varying risk groups for acquired immune deficiency syndrome. J. Clin. Invest. 78:977-982.
31. Washburn, R. G., C. U. Tuazon, and J. E. Bennett. 1985. Phagocytic and fungicidal activity of monocytes from patients with acquired immunodeficiency syndrome. J. Infect. Dis. 151:565-566.

32. Gaither, T. A., C. H. Hammer, J. E. Gadek, K. Katusha, M. Santaella, and M. M. Frank. 1983. Cleavage of membrane-bound C3b and C3bi by viable human neutrophils (PMN). Mol. Immunol. 20:623635 .

33. Kornfeld, H., R. A. Vande Stouwe, M. Lange, M. M. Reddy, and M. H. Grieco. 1982. T-lymphocyte subpopulations in homosexual men. N. Engl. J. Med. 307:729-731.

34. Fahey, J. L., H. Prince, M. Weaver, J. Groopman, B. Visscher, K. Schwartz, and R. Detels. 1984. Quantitative changes in T helper or T suppressor/cytotoxic lymphocyte subsets that distinguish acquired immune deficiency syndrome from other immune subset disorders. Am. J. Med. 76:95-100.

35. Stahl, R. E., A. Friedman-Kien, D. Dubin, M. Marmor, and S. Zolla-Pazner. 1982. Immunologic abnormalities in homosexual men. Am. J. Med. 73:171-178.

36. Chess, Q., J. Daniels, E. North, and N. T. Marcris. 1984. Serum immunoglobulin elevations in the acquired immunodeficiency syndrome (AIDS): IgG, IgA, IgM, and IgD. Diagn. Immunol. 2:148-153.

37. McDougal, J. S., M. Hubbard, J. K. A. Nicholson, B. M. Jones, R. C. Holman, J. Roberts, D. B. Fishbein, H. W. Jaffe, J. E. Kaplan, T. J. Spira, and B. L. Evatt. 1985. Immune complexes in the acquired immunodeficiency syndrome (AIDS): relationship to disease manifestation, risk group, and immunologic defect. J. Clin. Immunol. 5:130138.

38. Murray, H. W., B. Y. Rubin, H. Masur, and R. B. Roberts. 1984. Impaired production of lymphokines and immune (gamma) interferon in the acquired immunodeficiency syndrome. $N$. Engl. J. Med. 310:883889. 